\title{
Фитомониторинг состояния рекреационных зон г. Костаная методом флуктуирующей асимметрии на примере тополя бальзамического (Populus balsamifera)
}

\section{Phytomonitoring of the state of recreational zones in Kostanay using fluctuating asymmetry method on Populus balsamifera}

\author{
Кобланова С. А., Бакытбеккызы А. \\ Koblanova S. A., Bakytbekkyzy A. \\ Костанайский государственный университет им. А. Байтурсынова, г. Костанай, Казахстан. \\ E-mails:ainur_bakytbek@mail.ru; saule200707@inbox.ru \\ Kostanay State University n. a. A. Baitursynov, Kostanay, Kazakhstan
}

\begin{abstract}
Peфepam. В статье приведены результаты фитомониторинга состояния рекреационной зоны г. Костаная на примере парка «Бульвар молодежи». Исследование проводилось с помощью метода флуктуирующей асимметрии на примере тополя бальзамического (Populus balsamifera).
\end{abstract}

Ключевые слова. Билатеральные признаки, интегральный показатель, рекреационные зоны, фитомониторинг, флуктуирующая асимметрия.

Summary. The article shows the results of phytonomonitoring of the recreational zone's state in Kostanay on the example of Park "Youth Boulevard". Investigation was carried out using the method of fluctuating asymmetry on the example of Populus balsamifera.

Key words. Bilateral signs, fluctuating asymmetry, integral index, recreational zones, phytomonitoring.

Город Костанай - административный центр Костанайской области, расположенный на северо-западе Казахстана. Его общая площадь составляет 240 км²$^{2}$, город расположен на Костанайской равнине, на севере Тургайского плато, на левом берегу р. Тобола.

Город расположен на стыке лесостепной и степной зоны. К юго-западной границе города примыкают разнотравно-ковыльные степи, а к северо-восточной - сосновые и сосново-березовые леса. В поймах небольшими участками встречаются луга. По берегу р. Тобола и озер произрастает водная и околоводная растительность (Воронов, 1964). В городе находятся несколько парков, а также имеются небольшие скверы и аллеи.

Основная масса зеленых растений приходится на долю рекреационных зон города. Нами был проведен фитомониторинг состояния одной из молодых рекреационных зон города Костаная - это «Бульвар молодежи», представляющий собой парк площадью 48,31 кв. м, который был открыт 1 июня 2013 г. Основной функцией рекреационной зоны является снижение нагрузки на окружающую среду наиболее загрязненного района города. Видовое разнообразие представлено следующими древесными видами: тополь бальзамический (Populus balsamifera L.), сосна обыкновенная (Pinus sylvestris L.), клен остролистный (Acer platanoides L.), береза повислая (Betula pendula Roth.), вяз обыкновенный (Ulmus laevus Pall.). (Булыгин, 2003)

Парк «Бульвар Молодежи» расположен в районе КСК (комвольно-суконный комбинат), на пересечении улиц Кобыланды батыра - Каирбекова - Текстильщиков. Он был образован на территории, где уже произрастали тополя (Populus balsamifera L.) возрастом 30-40 лет. Данный вид часто используется как вид - индикатор качества городской среды, и поэтому нами в данном исследовании были использо- 
ваны методы расчета интегрального показателя флуктуирующей асимметрии (ФА) на примере листьев тополя бальзамического (Захаров, Баранов, 2000).

Исследование было проведено в период с августа 2018 г. по ноябрь 2018 г. Листья отбирались с трех ключевых участков: 1 - ключевой участок вдоль ул. Кобыланды батыра; 2 - ключевой участок по центру парка «Бульвара молодежи»; 3 - ключевой участок вдоль ул. Каирбекова. На каждом ключевом участке были выбраны 10 деревьев и с каждого дерева отбирались образцы листовых пластинок (по 50 шт.).

Показатели флуктуирующей асимметрии рассчитывали по пяти билатеральным признакам листовой пластинки: ширина половины листа; длина второй жилки второго порядка от основания листа; расстояние между основаниями первой и второй жилок второго порядка; расстояния между концами первой и второй жилок второго порядка; угол между главной жилкой и второй жилкой второго порядка.

У каждой листовой пластинки были проведены измерения по пяти признакам (Захаров, Баранов, 2000) и вычислен коэффициент их среднего значения (табл. 1). Измерения проводились в сантиметрах (признак 1-4) и градусах (признак 5).

Таблица 1

Среднее значение исследуемых признаков по ключевым участкам

\begin{tabular}{|l|c|c|c|}
\hline \multirow{2}{*}{\multicolumn{1}{|c|}{ Признак }} & \multicolumn{3}{|c|}{ Ключевой участок } \\
\cline { 2 - 4 } & 1 & 2 & 3 \\
\hline Ширина листовой пластины справа & 4,0 & 3,7 & 3,2 \\
\hline Ширина листовой пластины слева & 4,2 & 3,2 & 3,3 \\
\hline Длина 2-й жилки 2-го порядка справа & 4,7 & 4,5 & 4,3 \\
\hline Длина 2-й жилки 2-го порядка слева & 4,0 & 4,4 & 4,0 \\
\hline Расстояние между основаниями 1-й и 2-й жилок справа & 0,5 & 0,6 & 0,2 \\
\hline Расстояние между основаниями 1-й и 2-й жилок слева & 0,3 & 0,8 & 0,3 \\
\hline Расстояние между концами 1-й и 2-й жилок справа & 3,5 & 2,7 & 2,8 \\
\hline Расстояние между концами 1-й и 2-й жилок слева & 3,2 & 2,5 & 2,9 \\
\hline Угол между главной и 2-й жилкой справа & 45 & 43 & 52 \\
\hline Угол между главной и 2-й жилкой слева & 42 & 40 & 45 \\
\hline
\end{tabular}

Далее были определены различия между значениями признака слева и справа - для каждого признака. Для этого определили разность значения измерений по одному признаку для одного листа, затем нашли сумму этих же значений и разность поделили на сумму. Данные вычисления производили по каждому признаку (от 1 до 5). В результате получили 5 значений ординаты для каждого листа. Затем нашли значение среднего относительного различия между сторонами на признак для каждой листовой пластинки. Для этого сумму относительных различий делили на число признаков. Подобные вычисления производили для каждого листа. Далее вычислили средний коэффициент значения различия между стороной и признаком. Для этого все значения сложили и поделили на число этих значений, т. е. число листьев. Полученный показатель характеризует степень асимметричности организма. При вычислении мы нашли следующие интегральные показатели стабильности развития (Захаров, Баранов, 2000):

1 ключевой участок - 0,047;

2 ключевой участок - 0,044 ;

3 ключевой участок $-0,049$.

Согласно шкале оценки отклонений состояния организма от условной нормы (табл. 2) ключевые участки 1 и 3 оказались загрязненными, а 2 ключевой участок менее загрязненный, так как растения на данном участке испытывали слабое влияние неблагоприятных факторов (табл. 3).

Анализ результатов исследований свидетельствует о том, что динамика формирования листа тополя бальзамического (Populus balsamifera L.) нарушена. Лист формируется с отклонениями, что характеризует реакцию растений на стресс-фактор (антропогенный фактор) (Собчак и др., 2013). 
Таблица 2

Шкала оценки отклонений состояния организма от условной нормы (Захаров, Баранов, 2000)

\begin{tabular}{|c|c|c|}
\hline Балл & Качество среды & Величина показателя стабильности развития \\
\hline I & Условная норма & $<0,040$ \\
\hline II & $\begin{array}{c}\text { Растения испытывают слабое влияние } \\
\text { неблагоприятных факторов }\end{array}$ & $0,040-0,044$ \\
\hline III & Загрязненные районы & $0,045-0,049$ \\
\hline IV & Сильно загрязненные районы & $0,050-0,054$ \\
\hline
\end{tabular}

Таблица 3

Значения показателя асимметричности листовых пластин (Захаров, Баранов 2000)

\begin{tabular}{|c|c|c|c|}
\hline Ключевой участок & Значение показателя асимметричности & Балл & Качество среды \\
\hline 1 & 0,047 & III & Загрязненные районы \\
\hline 2 & 0,044 & II & Относительно загрязнено \\
\hline 3 & 0,049 & III & Загрязненные районы \\
\hline
\end{tabular}

Полученные нами данные показали, что листовые пластинки, собранные на участках на окраине парка вблизи автомобильных дорог (ул. Кобыланды батыра и ул. Каирбекова), характеризуются более высокими интегральными показателями, чем листья, собранные в центре рекреационной зоны парка «Бульвар молодежи».

Таким образом, неблагоприятное состояние рекреационной зоны парка «Бульвар молодежи» г. Костаная находит отражение в показателях асимметрии листьев тополя бальзамического (Populus balsamifera L.). Экологические особенности окружающей среды г. Костаная - это прежде всего выхлопные газы автотранспорта на загруженных им улицах, которые отрицательно влияют на жизненные процессы зеленных насаждений и на продолжительность их жизни. И это, в свою очередь, должно вызвать тревожность у жителей исследуемого района и способствовать принятию необходимых мер администрацией города. Следует продолжить работы по озеленению города, увеличить количество скверов, парков, аллей, создать новые автомобильные развязки и дороги в целях уменьшения автомобильных пробок и выброса загрязняющих веществ в атмосферу (Громадин, Матюхин, 2012).

\section{ЛИТЕРАТУРА}

Булыгин Н. Е. Дендрология. - МГУЛ, 2003. - 528 с.

Воронов А. Г. Биогеографические очерки Кустанайской области. - М.: Изд-во Московского ун-та, 1964. $228 \mathrm{c}$.

Громадин А. В., Матюхин Д. Л. Дендрология. - Академия, 2012. - 148 с.

Захаров В. М., Баранов А. С. Здоровье среды: методика оценки. - Центр экологической политики России, 2000. -129 c.

Собчак Р. О. Афанасьева Т. Г. Копылов. М. А. Оценка экологического состояния рекреационных зон методом флуктуирующей ассиметрии листьев Betula pendula Roth. // Вестник Томского государственного университета, 2013. - C. 195. 